cotyledons and Sikkim plants to the Department. The present collection is estimated at 40,000 sheets, in excellent condition and order. Its chief value is in Mr. Lacaita's own gatherings from various parts of Europe but particularly from Italy and Spainareas not over-well represented in the herbarium. There is further abundant material of those genera in which he had specialised, such as Helianthemum, Echium, Onosma, Pulmaria and Cirsium. The collection also contains a number of exsiccata, some of which were not previously represented in the Museum collections. Mr. A. H. G. Alston, assistant keeper in the Department, visited southern Albania in the summer in company with Mr. N. Y. Sandwith, of the Kew Herbarium. They explored many districts from which no previous collections are known. About a thousand different plants were collected. Although these have not yet been worked through, they evidently include many rare and little-known species. The collection, in conjunction with that made in Macedonia last year, will give a good deal of information about plant distribution in the Balkan Peninsula. Mr. G. Tandy, assistant keeper in the Department, has again visited the Tortugas, Florida, and has collected about 650 numbers. These contain a very interesting series from experiments on growthforms of species of Caulerpa, which will yield valuable taxonomic results. Mir. J. Gossweiler has presented a further 433 specimens of Angola flowering plants.

\section{Friends of the National Libraries}

THE Friends of the National Libraries, a body formed in 1931 to promote and assist in the acquisition by the national libraries of important works and manuscripts, has issued its second annual report, covering the year ending March 31, 1933 (Friends of the National Libraries, c/o British Museum, W.C.1). It is obvious that the main task of such a society must be to fill the gaps existing in the great collections of the British Museum, the Bodleian, and the other national libraries of Great Britain, and it is therefore all the more gratifying to find from the present report that the interests of the smaller and the special libraries are not being overlooked, and that many of the works secured during the year have gone to them. A notable example is the acquisition by the Royal Entomological Society of the first nine numbers of its own early Journal of the Proceedings of the Entomological Society of London, 1840-1846. Only ten numbers of this journal were issued (the Proceedings were incorporated with the Transactions from 1847 until 1926), and though copies were widely distributed at the time, they seemed to have become exceedingly rare and have for long been included in the desiderata of the Society's library.

Among other gifts of the Friends of the National Libraries, we find that four Linnæus items, including a unique copy of the fourth edition of Rousseau's "Letters on the Elements of Botany", 1794, have gone to the Natural History Museum, whilst the Science Library has benefited to the extent of more than a hundred volumes on navigation and kindred subjects. The latter formed part of a collection of books placed by the Corporation of Trinity House at the disposal of the Friends of the National Libraries for distribution, and show the Society in its secondary rôlo-as a clearing-house for unwanted and duplicate books. This is a service that should be widely known and utilised, for it provides the only means whereby works of mainly local or other special interest can find a permanent home in the libraries most fitted to receive them. The excellent record of work shown in this report deserves to be copied, and it may be suggested that 'friends of the national museums' should similarly organise themselves to help the Science Museum and others to add to their collections.

\section{Chemical Engineering, Past and Present}

Prof. G. T. Morgan, director of Chemical Research under the Department of Scientific and Industrial Research, delivered a lecture before the Institution of Chemical Engineers on October 27 entitled, "Engineering in the Service of Chemical Research". Prof. Morgan is one of the exponents of high pressure chemistry, in which strong steel containers or autoclaves replace the glass test-tubes of the chemist. He described his successes at the Chemical Research Laboratory with pressures of 200 atmospheres at $450^{\circ} \mathrm{C}$. in inducing methyl alcohol and carbon monoxide to combine in the synthetic production of acetic acid. Apparatus has now been devised by which experiments can be carried out on pressures of 3,000 atmospheres, that is, about 20 tons per sq. in. The pressure-resisting parts for this plant are made from Sheffield nickel chromium molybdenum heat-treated steel. The plant is enclosed within steel screens so arranged that the various controls are operated from outside this protection. At the other extreme, constituents of coal tars difficult of separation are being obtained at the Laboratory by distillation of the tar at very low pressure (of the order of a thousand millionth of an atmosphere) in a plant in which the cold condensation surface is placed so near the substance being distilled that its molecules escape direct to the condensing surface without contamination.

Prof. Morgan demonstrated the efficiency of a new wetting agent for mercerising cotton, developed at the Laboratory from coal-tar products, which is now being marketed under the name of Shirlacrol. He also described a new ether extracting plant, developed at the Laboratory, by which a Yorkshire firm is now successfully manufacturing resorcinol, a 'fine' chemical of considerable industrial importance, supplies of which have hitherto been entirely imported from abroad. All industrial applications of chemical science, engineering and chemistry are mutually indispensable and, so far as Great Britain is concerned, the advantages of such co-operation are more generally recognised to-day than they formerly were, but there is room for much improvement. Opportunities are boundless but without a closer collaboration between chemistry and engineering, we must certainly drift into the position of a 
navvy nation-hewers of wood and drawers of water for more educated peoples. In certain respects Great Britain was approaching that position in 1914. The War gave us a temporary respite, but the never-ending economic industrial struggle is still with us, and in this contest the intimate blend of chemistry and engineering presented by the Institution of Chemical Engineers must take an increasingly important part.

\section{Elm Disease in Great Britain}

A Furthen survey to determine the course of elm disease in Great Britain was carried out recently by Mr. T. R. Peace, of the Imperial Forestry Institute, Oxford, on the instructions of the Forestry Commissioners. Three counties have now to be added to the list of those in which the disease is known to occur, namely Durham, Derbyshire and Dorset. The characteristic symptoms of elm disease, namely dieback of the crown, appeared this year rather earlier than usual and by the end of July so many cases were seen that a heavy attack appeared probable. Surprisingly few further cases, however, developed during August and September and the final result may be stated as showing a definite increase over 1932 but a decrease as compared with 1931. The general position in England is unchanged from that of previous years. The disease remains serious in parts of the eastern counties; but severe damage is of local occurrence. In the South Midlands and in the south eastern counties the disease is frequent but seldom serious. Towards the west and north it is sporadic and has not been found north of a line between Durham and Chester, in the western counties of Wales, or in Cornwall. Having regard to the recent dry summer, it may be considered satisfactory that the disease has not spread more rapidly or done a larger amount of damage than appears to be the case. An interesting observation made during the course of the survey relates to the north of England and Scotland. Many of the older trees, mostly wych elms, showed signs of die-back elosely resembling those caused by the elm disease, but distinguished from the latter by the absence of the characteristic markings in the twigs and by one or two more general characters such as the browning of the leaves round the edges. The cause of the trouble, which is widespread, is under investigation.

\section{The Communication Revolution, 1760-1933}

AFTER the delivery of the presidential address by Mr. H. W. Dickinson to the Newcomen Society on October 11, a paper with the above title was read, by Prof. R. G. Albion of Princeton University. Taking the opening of Brindley's Bridgewater Canal as his starting point, Prof. Albion touched upon the development of canals, roads, railways, steam. ships, telegraphs and submarine cables, electric traction, motor-ears, telephones, aeroplanes and radio, and briefly referred to the effect of the 'communication revolution' on commerce, finance, exploration, colonisation, government, warfare, city growth and also to its influence on the individual. His paper contained many interesting comparisons of the facilities for communication in the eighteenth century and to-day. Just as stage coaches in England sometimes took 14 days to go from London to Edinburgh, so travellers were often a week going from Boston to New York, while one landmark in colonial travel was the inauguration in 1770 of a two-day service between New York and Philadelphia, a distance of but 90 miles. The first shots in the American Revolution were fired at Lexington on April 19, 1775, and the news did not reach New York, 225 miles distant, until four days later. The United States, Prof. Albion said, would probably have never fought England in 1812 had there been an Atlantic cable, for England suspended the Orders in Council, the chief American grievance, the day before War was declared at Washington. Rapidity of communication has also revolutionised business transactions, and although the Rothschilds once maintained an elaborate service of correspondents and couriers for business purposes, their information was neither so full nor so fresh as that found in any daily paper to-day. Speaking of newspapers, films and radio as the means for "mass communication" Prof. Albion said that the chief implied danger of these is that their great influence may be abused by the small groups which control them.

\section{Work of the Government Chemist}

THE report of the Government Chemist on the work of the Government Laboratory for the year ending March 31, 1933, shows that the total number of samples examined, nearly 461,000, was smaller by about 12,000 than last year's figure. Work actively progressed in the elucidation of new and improved methods, and in the technique of examination of materials becoming subject to new duties. For example, orders are made from time to time under the Import Duties and Ottawa Agreements Acts which involve changes in the incidence of duty and require the carrying out of many difficult analyses, of a wide range of products ; moreover, such analyses frequently require investigation and general inquiries before decisions can be reached. Among the specific investigations mentioned is one group on Trinidad natural gas, which was found to contain only negligible traces of helium. In 20 instances out of 105 samples of non-alcoholic beer, herb beer, and beer substitutes examined, the alcohol ranged from 2 to 6 per cent of proof spirit. Samples of storm water taken from surface water drains in London districts were examined chemically and bacteriologically in connexion with an inquiry into the character of the water concerned; the examination of numerous samples of sea-water has also been continued as a share in an international scheme for the collection of data for hydrographic research. Another phase of the work is designed to ascertain the condition of fishing streams from the point of view of fish life, and the effect of certain types of pollution on fish food. Reference is again made to the fact that since there are no regulations relating to the marking of skimmed or partly skimmed milk cheese, and since there is no standard for cream in Great Britain, no exception could be taken to deficiencies in the fat content of these foods. 